Johan Fourie

Associate Professor,

Department of

Economics, Stellenbosch

University.

johanf@sun.ac.za

DOI: https://dx.doi.

org/10.18820/24150509/

JCH42.v1.4

ISSN 0258-2422 (Print)

ISSN 2415-0509 (Online)

Journal for

Contemporary History

2017 42(1):59-80

(c) UV/UFS

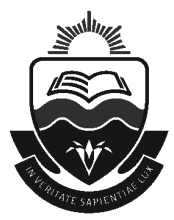

\section{THE LONG WALK TO ECONOMIC FREEDOM AFTER APARTHEID, AND THE ROAD AHEAD}

\begin{abstract}
As South Africa moves further away from the political transition of 1994, the economic history of the post-apartheid era is coming up for debate. The optimism generated by the ANC's early successes must now, after more than two decades of democracy, be tempered by its conspicuous failures. Over the last eight years in particular, the material welfare of South Africans have declined across large parts of the income distribution and the most damage was done to the poorest. Not all is lost though. African growth, technological innovation and private-sector participation in public sector services offer credible opportunities for accelerated development, but will only be effective if policy-makers are cognizant of the political realities. Well-directed and cheap policy interventions, like family planning, early-childhood education, free Wi-Fi in urban centres, and work visas and citizenship to highly-qualified foreigners can have dramatic and long-term effects. Policies, such as a youth subsidy, free tertiary education and charter schools would be more expensive - and more difficult, politically but they would clear some bottlenecks in the labour and education sectors. Unfortunately though, the long walk to economic freedom for many will continue along a road full of potholes.
\end{abstract}

Keywords: South African economy; democracy; post-apartheid; poverty; inequality; growth; development; Thabo Mbeki; Jacob Zuma; Trevor Manuel.

Sleutelwoorde: Suid-Afrikaanse ekonomie; demokrasie; post-apartheid; armoede; ongelykheid; groei; ontwikkeling; Thabo Mbeki; Jacob Zuma; Trevor Manuel.

\section{INTRODUCTION}

The Nobel-prize winning economist, Amartya Sen (1999), defined development as the existence of three linked freedoms: political freedom, freedom of opportunity and economic protection from abject poverty. When Nelson Mandela was inaugurated as the first democratically elected president of the Republic of South Africa on 10 May 1994, his and many South Africans' long walk to political freedom, the first of Sen's freedoms, had finally come to an end. Yet, for many an arduous and equally 
long walk to economic freedom lay ahead. This article assesses South Africa's post-apartheid economic transition twenty-two years after democracy, discusses the reasons for the successes and failures, and considers the road ahead.

By 2016, twenty-two years after the peaceful transition to democracy, not all South Africans have obtained the freedom of opportunity or economic protection from abject poverty. The South African government acknowledges this in its National Development Plan (NDP), released in early 2013 by the National Planning Commission; a strategic document meant to guide policy-making and budget allocation over the next two decades. ${ }^{1}$ Its goal is to eliminate poverty and to reduce inequality by 2030 . The document tackles many of the issues that were identified in the National Planning Commission's Diagnostic Report published two years earlier. This Report identified nine challenges, with the NDP proposing specific policies to address these challenges - too few jobs, poor education quality, inadequate infrastructure, a resource-intensive growth path, spatial challenges, an ailing public health system, poor performance of public service, corruption, and deep divisions within society.

The NDP is of course not the first post-apartheid policy document attempting to tackle South Africa's high levels of poverty and inequality. The Reconstruction and Development Programme (RDP, 1993), Growth, Employment and Redistribution Programme (GEAR, 1996), and Accelerated and Shared Growth Initiative of South Africa (ASGISA, 2006) were all designed to accelerate economic growth and reduce poverty. And, as is explained underneath, they were largely deemed successful, despite persistently high unemployment and inequality, rapid economic growth and lower poverty rates recorded.

This was achieved through careful fiscal management: reducing budget deficits, debt burdens and inflation, and large-scale redistribution through social transfers, notably pensions and child-support grants, spending on service infrastructure. A more stable macroeconomic environment improved the investment climate, boosting competitiveness and productivity. South Africa's social transfers are still precisely targeted at those who need it most.

But other microeconomic policies were less successful. Education outcomes at all levels of tuition lagged. Although primary and secondary education received significant budgetary support, little teaching happened in the classroom. The bimodal distribution of math and reading scores between those students in former white schools and those in former black schools today, is the result of an inability to improve the quality of teaching and learning in former black schools after 1994.

Domestic and international events since 2007 have shifted the economic prospects downward. The resignation of Thabo Mbeki and his succession by a more populist Jacob Zuma meant that the state wage bill escalated at the same

1 The National Development Plan is available online at, <http://www.gov.za/issues/nationaldevelopment-plan-2030>. 
time as the global financial crisis struck, reducing government revenue. In the years following the crisis, the budget surplus disappeared and was replaced by a persistently high budget deficit, providing less and less scope by government to redistribute expenditure towards the poor. Corruption increased, infrastructure deteriorated and state capacity to tackle the country's most pressing needs grew weaker.

The NDP is an attempt to fix these issues, but its broad scope and the amount of political capital required to implement the changes meant that it has remained little more than a policy document written to quell investors' concerns. It has - and it is likely to have - little effect on those who mostly depend on its successful implementation: South Africa's poor. For that reason a new approach is necessary, one that is cognizant of the political realities and constraints on state capacity.

\section{THE INHERITANCE}

As South Africa moves further away from the political transition of 1994, the economic history of the post-apartheid era is coming up for debate. The optimism generated by the African National Congress (ANC)'s early successes must now, after more than two decades of democracy, be tempered by its conspicuous failures. Poverty, although down from 1994, persists. Crime and corruption are pervasive and inequality, as Thomas Piketty argued in his 2015 Nelson Mandela Lecture, has widened: South Africa in 2015 is a more unequal society than South Africa under apartheid. ${ }^{2}$

What became known as a political miracle saw South Africa peacefully transform from white minority rule to democracy. But economic transformation has not followed suit. Although significant progress has been made, it was slow and often stunted. This is not only the fault of the post-apartheid government. The dismal state of the economy it inherited at the dawn of democracy has made it hard for the new ruling party to create the society it envisaged in its RDP, where everyone would enjoy a, "decent living standard and economic security". ${ }^{3}$ When the South African economy was opened up to the global marketplace, many of the country's oligopolies began to face tough competition and had to become more efficient. The 1990s' international economic zeitgeist did not promote Keynesian spending. Instead, economists were confident that spending frugally, cutting back on debt and containing inflation were the answers to the country's problems. This meant that South Africa's new government had to balance the

2 The full Nelson Mandela Lecture is available online at, <www.nelsonmandela.org/content/ annual-lecture/annual-lecture-201n5>.

3 The full text of the Reconstruction and Development Programme has been reproduced by Padraig O'Malley and is available online at, <www.nelsonmandela.org/omalley/ index.php/site/q/03lv02039/04lv02103/05lv02120/06lv02126.htm>. 
immediate needs of the poor with the need for macroeconomic stability by adhering to, what later became known as, the Washington consensus, a set of macroeconomic indicators that would satisfy investors and the international financial institutions. This goal was most succinctly described in GEAR, the Growth, Employment and Redistribution Act of 1996.

A decade after GEAR it seemed the balance had been found: 2007 started with many reasons for optimism about the state of the economy and the ability of the ANC government to alleviate poverty. Between 2004 and 2007, GDP growth averaged above 5\% per annum (World Bank 2016), which meant that government revenue increased faster than expenditure and Finance Minister Trevor Manuel could announce a surplus in his budget speech of February 2007 (National Treasury 2007). This growing economy not only created jobs in the private sector, it also meant that the government had the resources to continue expanding social security grants.

The result was that poverty declined, though not as fast as the economy grew. Using the Income and Expenditure Survey, Bhorat and Van der Westhuizen (2010) calculated that the poverty headcount ratio fell by only five percentage points between 1995 and 2005. Chief among the reasons for this somewhat slow decline was South Africa's integration into the global economy, which obliged many of the country's largest firms to increase efficiency. The immediate reaction was to cut costs and, consequently, jobs, especially those of unskilled or semi-skilled workers (Edwards and Behar 2006). This had the advantage of increasing labour productivity, the main reason for the fairly high post-apartheid economic growth rates. Higher labour productivity meant more pay for formal sector employees, but it also increased the inequality between those with work and those without.

Counteracting these changes was the extensive and well-targeted social security system that South Africa set up during the late stages of the apartheid regime and expanded during the 1990s and 2000s. The most important grants were (and continue to be) the old-age pension, the disability grant and the child support grant - the latter introduced in 1998 and expanded several times after that. Armstrong, Lekezwa and Siebrits (2008) show that government spending on these grants increased from 1,9\% of GDP in 2000 to 3,3\% in 2007. During the same period, the number of beneficiaries increased from 3 to 12 million. They also calculate a hypothetical poverty rate in the absence of these social grants and found that without the grants poverty would have been 32\% higher in 2005 .

Poverty is, of course, multidimensional. Access to housing, electricity, water and sanitation will improve people's quality of life even if their income remains the same. Here, too, the ANC government did much to improve the living standards of those neglected by the former regime. Massive resource shifts to poorer schools reduced the difference between rich and poor in years of educational attainment (Van der Berg 2007). Access to healthcare, which 
was especially needed in the face of the HIVIAIDS epidemic, also improved substantially (Schneider and Stein 2001). To test whether such social service provision reduced poverty, Finn, Leibbrandt and Woolard (2013) constructed a multidimensional poverty index that included education (years of schooling and attendance), health (child mortality and nutrition) and living standards (cooking fuel, sanitation, water, electricity and assets). A standard money-metric index showed the poverty headcount declining from $37 \%$ to $28 \%$ between 1993 and 2010 , but their multidimensional index for the same period showed it declining from $37 \%$ to $8 \%$.

So it is clear that the first fourteen years of democracy saw a rapid improvement in social services for the poorest South Africans. Yet job creation slowed and in some sectors, such as agriculture, even declined. Many economists would call this an era of jobless growth, meaning that while access to services increased dramatically for the poor, their ability to participate in the formal economy remained limited (Aliber 2003). Others disputed the notion of "jobless growth", noting that employment increased significantly, despite the large number of new entrants into the labour market (Bhorat 2004).

Regardless, the poor did not benefit as much as those at the top. Leibbrandt, Wegner and Finn (2011) comments on the 1993 to 2008 period, "Earnings for those in the bottom deciles have not risen in real terms over the post-apartheid period and have fallen markedly relative to those in the higher deciles. Thus, having an earner with unskilled employment is no guarantee that a household will rise out of the lower deciles of the household income distribution."

Living standards have improved, yet opportunities to escape poverty and move up the economic ladder have not increased. This is because the foundation for access to the formal labour market - education - continues to be poor for those at the bottom of the income distribution. The large fiscal transfers poured into education by the ANC government have not generated better school performance or higher pass rates (even though more children go to school for longer). Van der Berg (2007) says that, "Despite massive resource shifts to black schools, overall matriculation results did not improve in the post-apartheid period. Thus the school system contributes little to supporting the upward mobility of poor children in the labour market."

To understand the lack of social mobility in South Africa, we need to delve into the roots of the inequality between the "connected", who have access to the formal labour market, and the "unconnected" who remain outside its remit.

\section{THE EIGHT LEAN YEARS}

The past eight years have unfortunately done little to improve the freedoms of opportunity and economic protection. Analysing the effects of the 2007/2008 global financial crisis and recession on child poverty in South Africa, Maisonnave 
et al. (2015) found that material welfare declined across large parts of the income distribution and that the most damage was done to the poorest South Africans, pushing them further below the poverty line and for longer.

This was because the slowdown of economic growth following the crisis in the rich world made it difficult for South African businesses to draw more jobseekers into the labour market. The rapid economic growth in China, India and several African countries softened the effect of the crisis on South Africa to some extent; high demand for minerals, for example, bolstered industries that employed large numbers of unskilled or semi-skilled workers. But this level of demand do not last, and in the past three years the slowdown in China's growth has caused a decline in mineral prices with devastating consequences for the mining industry. In response to lower demand, employment declined and wages stagnated. Labour responded; consider the R12,8 billion in wages that was lost because of strikes in 2013 and 2014, or the more than 10 million work days that were lost in 2014 alone (Department of Labour 2015).

These global trends combined with domestic politics into a toxic cocktail. Under Jacob Zuma, elected president in 2009, economic policy-making has been muddled. At least three departments - the National Treasury, the Department of Economic Development and the Department of Trade and Industry - have economic policy-making as their primary function. Complicated by ideological differences, the result of this overlap is inertia or, worse, conflict. Other inter-departmental conflicts were recently publicly exemplified by the stand-off between the Minister of Home Affairs, Malusi Gigaba, and the Minister of Tourism, Derek Hanekom, over the new visa regulations imposed by Home Affairs to prevent child trafficking. ${ }^{4}$ The regulations have caused a sharp reduction in tourists from some of the fastest growing tourism markets, severely affecting the domestic tourism industry and further reducing job opportunities. ${ }^{5}$

The past eight years have also exposed South Africa's lack of long-term public investment in infrastructure. Since 2008, demand for electricity has often outstripped supply, resulting in costly power failures that have almost certainly impeded private sector investment (Kohler 2014). The condition of the roads has mostly worsened, and even where it has improved, the viability of the financing arrangements to pay for the improvement has been questioned (Fourie 2008). Service delivery protests about the lack of basic infrastructure at the local government level occur on a near daily basis (Tsheola 2012). Part of this is a consequence of the poor performance of publicly-owned corporations, including Eskom (the electricity public utility responsible for the power failures) and South

4 This dispute was widely reported in the media. See, for example, <http://ewn.co.za/2015/07/30/Ministers-in-rare-public-spat-over-visa-regulations>.

5 See, for example, the Minister of Tourism's own estimates as reported by the SABC, $<w w w . s a b c . c o . z a / n e w s / a / 23 d c 400049 b 8 f 908949 a f e 8 b 2 d e b b 9 b 3 / N e w-v i s a-r e g u l a t i o n s-$ harm- tourism:-Hanekom-20150409>. 
African Airways, the national carrier, which continues to demand frequent bailouts (Tsheola, Ledwaba, and Nembambula 2013).

All of this points to the weak (and weakening) capacity of the state to deliver on its promises of driving economic transformation. It also suggests that solutions to the pressing and persistent problems of poverty and social immobility will have to be found outside the purview of government.

\section{SYSTEMIC BARRIERS TO OPPORTUNITY}

But we cannot blame the slow progress in opening up opportunities for the poor only on adverse global trends and weakening state capacity. South Africa's history of excluding the black majority from the institutions necessary for growth, such as private property and good education, means that a huge proportion of poor South Africans are thwarted by systemic barriers to upward mobility.

One thing we notice about the South African landscape, for example, is the way the poor are geographically trapped in poverty and have no opportunity to escape via the labour market. Jobs are mostly to be found in or close to cities, while unemployment is a largely rural phenomenon. Ardington et al. (2013) found that young people from rural areas face high costs when looking for a job because of the apartheid-driven mismatch between where the jobs are and where the workers are.

The spatial features of apartheid also remain visible in South Africa's cities. Because the poor often live on the outskirts, their transport to work and other services is costly in terms of both time and money. During the early 2000s, the average commute in Johannesburg is around 80 minutes one way and commuters in the lowest income bracket spend about $35 \%$ of their earnings on transport (Rospabé and Selod 2006). Such excessive transport costs make it near to impossible for households to save, or to invest in physical and human capital.

But to escape the cycle of poverty, people on the periphery of South Africa's cities need more than better basic services: they need better education. As Spaull (2013) says, one of apartheid's most lamentable legacies is the dual education system that has continued to persist after 1994, "[M]any of the exblack schools which were entirely dysfunctional under apartheid remain largely dysfunctional today. They are characterised by severe underperformance, high grade repetition, high dropout, and high teacher absenteeism. While many of these factors are certainly attributable to the socio-economic disadvantage of the students they serve, there is also an undeniable impact of more intangible elements such as ill-discipline, inefficient management, and low cognitive demand - all legacies of apartheid. This low quality of education is further accentuated when compared to former 'Model-C' schools (ex-white) which are 
not dissimilar to schools in developed countries - both in terms of educational inputs and educational outcomes."

This dual system results in two very different kinds of outcomes. Using the SACMEQ III data of 2007, Spaull (2013) calculates the distribution of Grade 6 reading performance by school wealth quartile. The median reading score of children in the wealthiest quartile is similar to that of children in developed countries. But children in the poorest three quartiles score equally badly on reading tests and their marks are even worse than those of children in many developing countries.

There are myriad reasons for the poor performance of South African schools. The poor quality of education and culture of education before democratic rule matter, but so do teacher quality (which persists because of strong trade unions that prevents teacher evaluation, for example) and other managerial deficiencies (Wills 2015). A lack of funding is not the main constraint.

This unequal system of education perpetuates the cycle of poverty. Poor children grow up on the peripheries of cities or in rural areas where schools are so bad that they add little value. Their parents travel a long way to work, spending much of their household budget and their time on commuting. They grow up with few skills, unequipped for anything but low-productivity, unskilled work, and thus few employment opportunities.

The reason for the shortage of employment opportunities for this class of jobseeker is that the minimum wages in South Africa are above the market wages because of the low level of productivity, despite improvements since 1994, of the South African labour force (Rodrik 2008). And the low level of productivity is a consequence of the historically poor performance of the education sector and the political power of unions; labour unions were the first to legally subscribe black members in the 1970s, garnering support for wage increases before black political parties were allowed. Capital deepening increased the demand for semiskilled and skilled workers, rather than unskilled workers. Those with formal sector jobs - the connected - saw their wages increase faster that productivity.

These high wages for unskilled workers in South Africa, compared with other middle-income countries, make footloose industries, such as clothing and textile manufacturing, uncompetitive. In other industries, such as agriculture, high minimum wages have also inhibited job creation. Between 2001 and 2012, employment in agriculture fell by $5,1 \%$. Bhorat et al. (2014) say, "There is a sense that this sector could have had the potential to absorb low-skilled labour yet is in decline, and in part because of poor levels of investment in this sector, and the imposition of the minimum wage."

That the minimum wage reduce employment confirms the findings of recent research by a team of agricultural economists at the Western Cape Department of Agriculture, which shows the decline in agricultural employment, notably for temporary workers, following the minimum wage increases on farms in the 
Western Cape in 2012 (Von Fintel, Garbers and Pienaar 2015). Minimum wage legislation blocked opportunities for those who hoped to escape poverty through (albeit temporary) participation in the labour market.

The country's severe shortage of skills, due to the poor level of education for the majority of South Africans, is best demonstrated by the difference in unemployment rates for graduates and non-graduates. In 2011, when the overall unemployment rate was $33,3 \%$, the unemployment rate for university graduates was only 4,9\% (Van der Berg and Van Broekhuizen 2012). For black graduates, the figure was slightly higher, at $7,7 \%$, but still significantly below the overall rate. And the benefits of lower unemployment and higher wages are not limited to university degrees. Krugell and Blaauw (2014) found that day-labourers receive a higher wage if they have other kinds of post-matric qualifications. Broadening access to tertiary education - not just degrees, but diplomas and certificates as well - is essential if South Africa is to fill its yawning skills gap.

A large pool of poorly educated unemployed youth is unfortunately likely to remain a reality of the South African labour market, with serious negative sideeffects for society. Faced with poor labour market conditions and unable to invest in their own human capital because they have been denied a proper education, many will be forced to find work in the informal sector. This sector offers little in the way of on-the-job skills acquisition. And crime, because it requires scarcely any initial investment in either physical or human capital, will continue to be an appealing trade for the young unemployed.

Moreover, these early years of no formal sector employment will scar them for life. New research shows that the initial experience of work is likely to affect a young person's future opportunities and living standards. A study from Germany shows that each day a person is unemployed during the first eight years on the labour market means an extra day of unemployment during the following 16 years (Schmillen and Umkehrer 2013). Preliminary findings for South Africa also point to significant scarring for black youth (Ismail and Kollamparambil 2015).

This large pool of unemployed youth has put pressure on the South African government to step in. One way to satisfy the demand is to create public sector jobs. This is indeed what has happened; over the past few years the public sector wage bill has increased rapidly (Burger and Calitz 2015). For the lucky few who graduate, the choice of career is not simple. The South African government and parastatals are eager to see their personnel adhere to the racial demographics of South Africa, drawing in a disproportionate number of black graduates. Government employment may seem a less risky occupation with higher starting salaries for young black employees than the entrepreneurial ventures their white compatriots are likely to engage in. Those who venture on their own may, instead of looking for opportunities to participate in the global market, find the lucrative black economic empowerment deals with the government and its parastatals more appealing. 
Global systemic shifts have not made things easier. While technology - the rise of robots - provides numerous consumer benefits, it is likely to continue replacing large numbers of unskilled labourers with smaller numbers of skilled workers. Industries like car manufacturing, that previously provided jobs for large numbers of unskilled labourers, are now automated. Rodrik (2015) calls this phenomenon "premature de-industrialisation". Whether the services industries telecommunications, travel, logistics, business process outsourcing - can create jobs on the scale that manufacturing did for the industrialised countries remains to be seen.

Kanbur (2015) summarises the interaction between global and domestic forces thus, "The juggernaut of technological change is displacing basic labour. Combined with a resistance to real wage reductions, there is high unemployment. With unemployment comes the pressure to expand employment in the public sector which, together with wage demands, leads to a rising public-sector wage bill. If the fiscal balance is protected through higher taxation, or if higher fiscal deficits elicit tight monetary policy, employment in the private sector is hit again adding to the way in which global forces contribute to rising unemployment. The spiral continues."

Such a spiral threatens to perpetuate the severe inequality that permeates South African society. The consequence is that those at the bottom of the income distribution are locked into a system that limits their opportunities for upward social mobility. Policies to break down these systemic barriers are the only way to open up opportunities for the next generation.

\section{OPENING UP OPPORTUNITIES FOR THE NEXT GENERATION}

What, then, can be done to open up opportunities for those that Amartya Sen would classify as unfree? Policies mostly come in two kinds: those that are politically acceptable, but costly, and those that are cost effective, but politically difficult to implement. The search is on for those low-hanging fruit that are cost effective and politically possible.

Socio-economic status remains one of the main determinants of a South African child's life opportunities. This status includes the parents' incomes, but also things like housing, water and sanitation, a safe neighbourhood, good schools and clinics and a job after leaving school. But even before birth, socioeconomic status matters. The socio-economic status of a child's mother is a strong determinant of the number of children she will have. The typical image of poverty in South Africa is an unemployed young black mother living in a rural area with several dependants.

One way to help these mothers, who often do not use modern contraception, to make better-informed life decisions is through state-sponsored 
family planning. A recent paper by Lumbwe Chola and four co-authors (2015) gives an idea of the benefits for mother and child health that a family planning initiative can bring. They calculate that an increase of $0,68 \%$ in the rate of contraceptive use would reduce the number of pregnancies from 1,3 million in 2014 to 1 million in 2030. Unplanned pregnancies, abortions and births would decrease by $20 \%$ and 7000 newborn and child, and 600 maternal deaths could be avoided at an annual cost of only US $\$ 33$ million (R430 million) per year.

Most unwanted children are born in poor families. Relatively cheap family planning can save these families from this burden. Empowering young mothers to make their own decisions will improve their health and safety and free up resources to invest in children born out of choice.

When children are born to parents with socio-economic opportunities, their early years, well-fed and cared for, are very different from those of children born to parents locked into poverty. The difference in school performance between rich and poor children is often the result of different investment during the first six years of a child's life. Spaull and Janeli Kotze (2015) found that poor performance in matric (the final year of high school in South Africa) can be traced to weak foundations in grades 1 to 3 and these weak foundations in school may, in turn, be traced to weak foundations at home.

This is why early childhood development is receiving attention from economists and other social scientists. It is increasingly clear that large gains accrue from investment in a child's early years. Heckman (2012), probably the leading scholar on education economics, says, "A critical time to shape productivity is from birth to age five, when the brain develops rapidly to build the foundation of cognitive and character skills necessary for success in school, health, career and life. Early childhood education fosters cognitive skills along with attentiveness, motivation, self-control and sociability - the character skills that turn knowledge into know-how and people into productive citizens."

Heckman investigated the Perry Preschool Programme in the United States (US) and calculated a return on investment of between $7 \%$ and $10 \%$ per year through better school and career achievement, as well as reduced costs through spending on remedial education, health and the criminal justice system (Conti, Heckman and Pinto 2015).

These early investments can take many forms: providing mothers basic necessities for newborns, giving them information about early childhood nutrition and health (see, for example, the llifa Labantwana Programme ${ }^{6}$ ), improving the way nursery school teachers interact with children in ill-equipped nurseries, or something as simple as a television programme aimed at mothers and children (Kearney and Levine 2015).

Early childhood development is one of the few spending categories that would win support across the South African political spectrum. Trade unions

6 More information available online at, <ilifalabantwana.co.za>. 
that hamper the transformation of the education system are less inclined to do so at the preschool level. There is thus no reason not to rapidly expand early childhood programmes across South Africa, particularly in poor areas. There is also ample opportunity to regulate private sector involvement.

A national pre-school scheme would not immediately make South Africa grow and prosper, but a new generation would grow up without glaring inequalities in the cognitive abilities that are already entrenched when a child starts school. Such a scheme could show voters and bureaucrats (and hopefully trade unions) the benefits, and perhaps even attract private sector participation, allowing the system to be expanded to primary and perhaps even secondary schools.

The impasse in South African education necessitates an innovative solution like this. Bad teachers, lack of managerial capacity, weak oversight by governing bodies, constantly changing curriculums and substandard facilities are some of the reasons for the poor numeracy and literacy scores reported above for the poorest three quartiles. Strong labour unions are preventing the implementation of progressive policies, even when promulgated by the Department of Basic Education. Trade union resistance to the implementation of the Annual National Assessments is a case in point.

Private schools in South Africa are providing good education to a growing number of pupils. The number of Curro schools in the country, for example, increased from 80 in 2014 to 101 in 2015, and several are under construction. These schools had more than 36000 pupils by June 2015, an increase of $26 \%$ on the previous year. ${ }^{7}$ It may be objected that Curro draws pupils from the upper part of the income distribution. But consider that in the absence of Curro the 36000 pupils who are now receiving a good education would have had to be accommodated in public schools, displacing another 36000 to poorer quality schools; the more good quality schools available, the better.

The possibility of importing the Curro model to lower or even low-income households must be investigated. One option is to design a system of charter schools where children receive a voucher and they can choose a private (if available) or public school. The feasibility of such an option is beyond the scope of this article and I want to stress that interest groups with heavy political clout will be against such a plan. But given the appalling state of the South African education system for the majority of South Africa's children and the importance of education for opening up opportunities for upward social mobility, such innovative solutions deserve further attention.

And yet, many high school students perform remarkably well despite the constraints of the education system. Of the total number who wrote the 2014 National Senior Certificate examination, 150752 or $28,3 \%$ qualified for

7 Curro Unaudited Results (2015), <www.curro.co.za/2015/8/13/Curro\%20unaudited\%20 interim\%20results\%2030\%20June\%202015\%20-\%20Press\%20release.pdf>. 
admission to bachelor studies. It is clear that not all of these could have come from the wealthiest quartile.

Unfortunately, not all of these students end up at South Africa's universities. It is mostly lack of finance that prevents them. ${ }^{8}$ Despite budget increases in the National Student Financial Aid Scheme over the past few years, many remain excluded. And even when students receive financial support, the administrative backlog in processing payments often results in rising tensions on campuses, as the \#FeesMustFall-movement of October and November 2015 clearly demonstrated.

One alternative is to make tertiary education free or, at minimum, heavily subsidised for the poorest students. The upside is that such a policy would receive political support from many interest groups. The downside is that it would be expensive and probably not realistic in the current fiscal climate. It is also likely to be a largely progressive expenditure item, as most students who qualify for university are from households in the wealthiest quartile of the distribution.

A more nuanced policy, maybe with a financial need assessment, could mitigate most of these concerns. Additional taxes, such as a wealth tax, could be earmarked explicitly for higher education. But a direct transfer in the form of a "graduate grant" to students who have shown themselves capable of obtaining a university degree would at least give those who have worked their way through an unfair schooling system the opportunity to benefit from their hard work. It would also be likely to increase the incentives for those still in school to improve their performance.

One area where free tertiary education could be most useful is in training new teachers. Van Broekhuizen (2015) notes that South Africa is currently not producing sufficient numbers of teacher graduates. The recent growth in the numbers qualifying is encouraging, but this growth will have to continue for the next decade to satisfy the projected teacher demand. And it is, naturally, not only the numbers that matter. "Even if the country manages to produce sufficient numbers of Initial Teacher Education (ITE) programme graduates in the next ten years, it remains unlikely that the types of teacher graduates that are produced will be the same as the types of teachers that are most needed in the schooling system."

Van Broekhuizen says greater emphasis must be placed on ensuring that ITE students graduate on time, that they specialise in high-demand subject areas like mathematics, and that they are transferred into the public teaching system with minimal delay. Here, again, private education may provide a solution: Curro has opened its own teacher training college to ensure a steady supply of teachers for its private schools; a model that can be expanded if a charter school system for poor schools can be developed.

8 The success rate of students at university is an important, but separate problem. 
But even if access to good tertiary education and training is expanded, a large pool of poorly qualified South Africans will still enter the labour market every year - those high-school graduates, for example, who have not qualified for admission to bachelor studies. To encourage firms to employ more young workers, a youth subsidy has been proposed by the ruling and the opposition parties. This proposal has received empirical support from James Levinsohn and three co-authors who found that young people, who were randomly allocated a voucher, were $25 \%$ more likely to be employed than those who were not. And in many cases the new recruits continued to be hired even after the programme had been abandoned (Levinsohn et al. 2014).

Ultimately though, unskilled labourers will increasingly be outcompeted by technology. The only way to improve their competitiveness will be to improve their opportunities for higher education and particularly for skills training. Youth wage subsidies in combination with private training colleges would be a relatively inexpensive way to even out some of the discrepancies between the poor and the wealthy.

Technology is of course not just a threat - it is also an opportunity in itself. These days, the classroom is not the only place where students can get a good education. The increasing availability of online tutorials and even degrees at a fraction of the cost of formal education and often free, allows access to knowledge and information previously reserved for the lucky few. But, as with other infrastructure services, ICT services are not yet equally available to everyone. While mobile access to the internet is widespread across South Africa, data services that enable students to download tutorials, or jobseekers to hunt for work opportunities, are not.

Fortunately, that is changing. Project Isizwe, for example, is rolling out free Wi-Fi in Tshwane and, within two years of implementation, has more than 300 000 unique users per month. ${ }^{9}$ Similar initiatives which are relatively cheap and would not require much political capital, are following in South Africa's other metros. And both Google and Facebook are designing new technologies that could revolutionise connectivity for those in rural areas..$^{10}$ Connecting the poorest South Africans to the knowledge and information available online is one of the low-hanging fruits South Africa can harvest in order to open up opportunities for the poor.

9 News update, <http://projectisizwe.org/>.

10 See, for example, <www.wired.com/2015/10/google-project-link/>. 
Johan Fourie $\cdot$ The long walk to economic freedom after apartheid, and the road ahead

\section{BROADER INVOLVEMENT}

The NDP was lauded by experts, both locally and internationally, when it was launched in 2013. ${ }^{11}$ It provides a clear road map for tackling the many binding constraints to alleviating poverty and reducing inequality. And yet, three years after the announcement of the Plan, South Africa has made little headway in addressing the issues raised in the Diagnostic Report. This is because, in the real world, the burden on government to implement the proposals, both in terms of capacity and in terms of political capital within the ruling party, was too demanding to succeed. The NDP has failed to deliver immediate returns, not because its policy advice was wrong, but because it requires the buy-in of too many actors across a wide spectrum of government departments and levels (Naidoo and Maré 2015).

Any policy approach to tackle poverty must be cognizant of the realpolitik of policy-making. It asks what can be achieved through the limited capacity and political capital of the political incumbent to improve the opportunities for the poorest. It does not propose a comprehensive mechanism to address all that is wrong. Instead, it limits its focus to those bottlenecks or binding constraints that prevent the social mobility of the poorest.

The policy initiatives described above do not address the many other issues that prevent the economy from growing and its people from prospering. Businesses need access to capital, a skilled (international) work force, affordable and reliable electricity, good quality roads and rails, a safe working environment, a non-corrupt judiciary, the protection of property rights, and efficient and transparent tax regulations, trade agreements, border posts and other governmental red tape. But coordinating these diverse policies is not easy, specifically when state capacity is weak and when political demands are pulling in different directions. Despite all the good intentions, the NDP has not expanded opportunities for the poor to prosper.

Instead, a focus on policies that expands the opportunities for young South Africans are most likely to find support across the political spectrum. And if narrowed to only five policy choices, such as being proposed here, the impact on poverty alleviation and social mobility is likely to be greater than an attempt to address a comprehensive set of social ills with little hope of implementation.

This is not to say that the South African government have not done much to expand opportunities within these three policy areas. In 2012, the Department of Health launched the National Contraception and Fertility Planning Policy, aimed at reprioritising contraception and fertility planning in South Africa. In March 2015, the Department of Social Development published a Draft National Early

11 See, for example, the response from Business Leadership South Africa, <http://www. businessleadership.org.za/gup/filez/Viewpoint_BLSA_Response_to_SA_National_ Development_Plan_May_2012.pdf>. 
Childhood Development Policy document. The main objective of the policy is to ensure universal quality early childhood development services for all South Africans. It envisages significant increases in the availability and delivery of early childhood development services. In 2012, the Report of the Working Group on Fee Free University Education for the Poor in South Africa was published, recommending that free university education for the poor is feasible, but that it would require significant additional funding.

But due to budget constraints and the low priority of many of these policies, few of these proposals have been implemented. This is also why a strong case can be made for greater private sector and NGO involvement in expanding opportunities for the poor. Note that this does not diminish the role of government; indeed, government is necessary to regulate, coordinate and monitor so as to prevent market failure. Instead of providing all services through public programmes, a shift in thinking towards government policy as regulator and overseer could not only reduce the burden on the fiscus, but improve the reach and quality of services provided to those most in need of it. Curro Schools (as a private sector initiative) and Project Isizwe (as a NGO initiative) are two cases in point.

\section{HOPEFUL SIGNS}

Despite the persistence of severe poverty and inequality in the South African society, there are reasons to be optimistic about the future. One source of optimism is, paradoxically, history. South Africans have had to confront far more serious challenges in their recent past; the transformation of 1994 is not called a "miracle" for nothing. And even when the international economy is struggling to emerge from a global recession and the rapid growth of the rising BRICS is faltering, South Africa has maintained positive, if low, economic growth rates. South Africans are resilient. Parts of the country, notably those areas in and around the three largest metros of Johannesburg, Tshwane and Cape Town, continue to see progress in service delivery and in job creation. That is also why large numbers of rural South Africans continue to migrate to these areas.

These metros are doing well, because growth in South Africa's economy is now based on producing goods and, importantly, services for the African market. "Africa rising" is a popular aphorism of the last decade and it continues to ring true. Nigeria, Africa's largest economy, and Kenya, East Africa's largest, have grown by an average of more than $5 \%$ per annum over the past five years (World Bank 2016). Namibia, Mozambique and Zambia, for all of whom South Africa is the largest importer, have grown at an average of $6 \%$ per annum over the past five years. South Africa supplies services such as logistics, construction, telecommunications, banking and retail to all five of these countries, which is one reason why the share prices of such firms on the Johannesburg Stock 
Exchange have not exhibited the same lacklustre growth as the South African economy. Even the slowing of growth in China is likely to have only a small effect on the growth of these markets, which are being fuelled, at least in part, by a burgeoning African middle class.

Demography is one reason why this middle class is growing. Africa's current population of roughly one billion people is made up mostly of young people. The continent is likely to double the number of inhabitants to two billion by 2050 , and quadruple to four billion by 2100 , to total more than a third of the world population. ${ }^{12}$ This will create competition for resources, but it will also open up a massive market for entrepreneurs to exploit. South Africa already shares a customs union with several neighbouring countries and a free trade area has recently been negotiated, stretching from Cape Town to Cairo. By exploiting these locational advantages, South African firms have an opportunity to profit from Africa's rise.

The demographic transition will also put more pressure on South Africa to welcome migrants from other African countries. This is likely to increase political pressure in South Africa, but could also offer an opportunity to alleviate the skills shortage the country will continue to face. There is general consensus amongst economists that immigrants have a net positive economic impact. Offering swift and affordable citizenship to highly qualified foreigners is another low-hanging fruit that can propel the economy forward with little additional cost and effort, building new enterprises and creating jobs.

Increasing internal pressure to satisfy the diverse demands within the ANC, its alliance partners and more legitimate external rivals, will likely eat into support for the party that has governed South Africa since 1994. Political competition, with no party enjoying a guaranteed majority, may ultimately be the only way to improve the capacity and coordination of state institutions (including parastatals) that have clearly weakened over the past decade.

\section{CONCLUSION}

Twenty-two years after democracy many South Africans have not yet gained the economic freedoms that Amartya Sen defined as the pillars of development. The past eight years have admittedly given fewer grounds for optimism than the history of the first fourteen years. Yet, all is not lost. Despite the poor performance of the global economy and the weakening of the South African policy environment, the South Africa economy is still, tenaciously, growing at positive per capita rates. But higher growth rates are necessary to create the opportunities for those at the bottom of the income distribution to move up. A few well-directed and relatively cheap policy interventions would help. Family

\footnotetext{
12 See, for example, <www.gapminder.org/videos/dont-panic-end-poverty/>.
} 
planning, early-childhood education, free Wi-Fi in urban centres, and work visas and citizenship to highly-qualified foreigners are affordable initiatives that can have dramatic and long-term effects. A youth subsidy, free tertiary education and charter schools would be more expensive - and more difficult politically - but they would clear some bottlenecks in the labour and education sectors.

Of course there are many other policies that could be implemented with varied outcomes and unintended consequences. Nationalisation, land redistribution, tax policy, and trade and industrial policy have been touted as ways to speed up the alleviation of poverty. But, because of their cost, they are unlikely to be implemented on a large scale and, more importantly, are unlikely to have the impact their proponents envisage. The weak capacity of the state (and its declining capabilities) to fulfil its traditional role of providing public services also suggests that there is little hope that such activist and large-scale state involvement in the economy will be anything but harmful. Instead, most of the low-hanging-fruit policies proposed here require the state to regulate the market, even in those sectors where the state usually had a monopoly. Curro has shown that privatising services that were usually provided by the state, can be a success. Why not replicate that success elsewhere as well: in health, in correctional services, in housing, in infrastructure provision and, critically, in the public school system?

The rhetoric of national government suggests that this will not happen soon though. South Africa will in all likelihood continue to "muddle along" for a good while to come. Improvements will be negligible, unless it brings the unconnected into the formal economy by equipping them with the necessary education and skills. And that will only happen if it ensures good education for children from the poorest sectors of society from early childhood development to tertiary education. Only then will the poor, as well as the wealthy, be able to profit from the endless opportunities that a rising Africa will offer in the coming decades.

\section{LIST OF SOURCES}

Aliber, M 2003. "Chronic poverty in South Africa: Incidence, causes and policies", World Development 31(3):473-490. https://doi.org/10.1016/S0305750X(02)00219-X

Ardington C, T Bärnighausen, A Case and A Menendez 2013. "Social protection and labour market outcomes of youth in South Africa", SALDRU Working Paper, University of Cape Town, No. 96.

Armstrong, P, B Lekezwa and K Siebrits 2008. "Poverty in South Africa: A profile based on recent household surveys", Stellenbosch Working Paper Series, Stellenbosch University, No. WP04/2008. 
Johan Fourie $\cdot$ The long walk to economic freedom after apartheid, and the road ahead

Bhorat, H 2004. "Labour market challenges in the post-apartheid South Africa", South African Journal of Economics 72(5):940-977. https://doi. org/10.1111/j.1813-6982.2004.tb00140.x

Bhorat, H, A Cassim and A Hirsch 2014. "Policy co-ordination and growth traps in a middle-income country setting: The case of South Africa", WIDER Working Paper Series, United Nations University, No. 2014/155.

Bhorat, $\mathrm{H}$ and $\mathrm{C}$ van der Westhuizen 2010. "Poverty, inequality and the nature of economic growth in South Africa". In: N Misra Dexter and J February (eds), Testing democracy: Which way is South Africa going?. Cape Town: Idasa, pp. 46-70.

Burger, P and E Calitz 2015. "Twenty-year review of South African fiscal policy: A tale of two sustainabilities", Development Southern Africa 32(6):1-19. https://doi. org/10.1080/0376835X.2015.1063989

Chola, L, S McGee, A Tugendhaft, E Buchmann and K Hofman 2015. "Scaling up family planning to reduce maternal and child mortality: The potential costs and benefits of modern contraceptive use in South Africa", PLOS ONE 10(6):e0130077. https://doi.org/10.1371/journal.pone.0130077

Conti, G, JJ Heckman and R Pinto 2015. "The effects of two influential early childhood interventions on health and healthy behaviors", NBER Working Paper, Cambridge, MA, No. w21454.

Department of Labour 2015. Annual Industrial Action Report 2014. Available online, <http://www.labour.gov.za/DOL/documents/annual-reports/industrialaction-annual-report/2014/annual-report-industrial-action-report-2014>.

Edwards, L and A Behar 2006. "Trade liberalisation and labour demand within South African manufacturing firms", Studies in Economics and Econometrics 30(2):1-20.

Finn, A, M Leibbrandt and I Woolard 2013. "What happened to multidimensional poverty in South Africa between 1993 and 2010?", SALDRU Working Paper, University of Cape Town, No. 99.

Fourie, J 2008. "A note on infrastructure quality in South Africa", Development Southern Africa 25(4):481-494. https://doi.org/10.1080/03768350802318639

Heckman, J. "Invest in early childhood development: Reduce deficits, strengthen Arizona's economy". Available online, <http://heckmanequation.org/download. php? file=040312_HeckmanDeficitPieceCUSTOM-Arizona.pdf>. 
Ismail, Z and U Kollamparambil 2015. "Youth unemployment duration and competing exit states: What hides behind long spells of black youth unemployment in South Africa?", African Development Review 27(3):301-314. https://doi.org/10.1111/1467-8268.12150

Kanbur, R "Labour and unemployment in South Africa: Notes towards a 'grand bargain'". Available online, <www.dpru.uct.ac.za/sites/default/files/image_tool/ images/36/Publications/Policy_Briefs/DPRU\%20PB\%2015-43.pdf>.

Kearney, MS and P Levine 2015. "Early childhood education by MOOC: Lessons from Sesame Street", NBER Working Paper, Cambridge, MA, No. w21229.

Kohler, M 2014 "Differential electricity pricing and energy efficiency in South Africa", Energy 64:1:524-532. https://doi.org/10.1016/j. energy.2013.11.047

Krugell, W and D Blaauw 2014. "Micro-evidence on day labourers and the thickness of labour markets in South Africa", South African Journal of Economic and Management Sciences 17(4):484-499. https://doi.org/10.4102/sajems. v17i4.763

Leibbrandt, M, E Wegner and A Finn 2011. "The policies for reducing income inequality and poverty in South Africa", SALDRU Working Paper, University of Cape Town, No. 64.

Levinsohn, J, N Rankin, G Robert and V Schöer 2014. "Wage subsidies and youth employment in South Africa: Evidence from a randomised control trial", Stellenbosch Working Paper Series, Stellenbosch University, No. WP02/2014.

Maisonnave, H, M Chitiga, B Decaluwé, R Mabugu, V Robichaud, D Shepherd, $S$ van der Berg and D von Fintel 2015. "The impact of the international economic crisis on child poverty in South Africa", Poverty \& Public Policy 7(2):176-199. https://doi.org/10.1002/pop4.100

Naidoo, V and A Maré 2015. "Implementing the National Development Plan? Lessons from co-ordinating grand economic policies in South Africa", Politikon 42(3):407-427. https://doi.org/10.1080/02589346.2015.1104466

National Treasury 2007. Budget speech 2007. Minister of Finance, Trevor Manuel, MP. Available online, <http://www.treasury.gov.za/documents/national\%20 budget/2007/speech/speech.pdf $>$.

Rodrik, D 2008. "Understanding South Africa's economic puzzles", Economics of Transition 16(4):769-797. https://doi.org/10.1111/j.1468-0351.2008.00343.x 
Johan Fourie $\cdot$ The long walk to economic freedom after apartheid, and the road ahead

Rodrik, D 2015. "Premature deindustrialization", NBER Working Paper, Cambridge, MA, No. w20935.

Rospabé, S and H Selod 2006. "Urban unemployment in the Cape Metropolitan Area". In: H Bhorat and R Kanbur (eds), Poverty and policy in post-apartheid South Africa. Pretoria: HSRC Press, pp. 262-287.

Schmillen, A and M Umkehrer 2013. "The scars of youth: Effects of early-career unemployment on future unemployment experience", Discussion Paper, IAB (Institute for Employment Research), Nuremberg, No. 6/2013.

Schneider, H and J Stein 2001. "Implementing AIDS policy in post-apartheid South Africa", Social Science \& Medicine 52(5):723-731. https://doi.org/10.1016/ S0277-9536(00)00174-X

Sen, A 1999. Development as freedom. Oxford: Oxford University Press.

Spaull, N 2013. "Poverty \& privilege: Primary school inequality in South Africa", International Journal of Educational Development 33(5):436-447. https://doi. org/10.1016/j.ijedudev.2012.09.009

Spaull, N and J Kotze 2015. "Starting behind and staying behind in South Africa: The case of insurmountable learning deficits in mathematics", International Journal of Educational Development 41:13-24. https://doi.org/10.1016/j. ijedudev.2015.01.002

Tsheola, JP 2012. "Theorising a democratic developmental state: Issues of public service delivery planning and violent protests in South Africa", Journal of Public Administration 47(1):161-179.

Tsheola, J, M Ledwaba and P Nembambula 2013. "State-owned enterprises on the global business stage: Whither the South African owner-publics?" Politeia 32(2):20-36.

Van Broekhuizen, H 2015. "Teacher supply in South Africa: A focus on initial teacher education graduate production", Stellenbosch Working Paper Series, Stellenbosch University, No. WP07/2015.

Van der Berg, S 2007. "Apartheid's enduring legacy: Inequalities in education", Journal of African Economies 16(5):849-880. https://doi.org/10.1093/jae/ejm017

Van der Berg, S and H van Broekhuizen 2012. "Graduate unemployment in South Africa: A much exaggerated problem", Centre for Development and Enterprise, Stellenbosch University. 
Von Fintel, D, C Garbers and L Pienaar 2015. "Agricultural minimum wages: An update following the 2012 farmworker strikes", Brown Bag Lunch Seminar Series, Stellenbosch University, 21 May.

Wills, G 2015. "Informing principal policy reforms in South Africa through databased evidence", South African Journal of Childhood Education 5(2):95-122. https://doi.org/10.4102/sajce.v5i2.392

World Bank 2016. "Annual percentage increase in Gross Domestic Product", World Development Indicators. World Bank, Washington, DC. Available online, http://data.worldbank.org/data-catalog/world-development-indicators. 